\title{
HOXA3 Gene
}

National Cancer Institute

\section{Source}

National Cancer Institute. HOXA3 Gene. NCI Thesaurus. Code C104331.

This gene plays a role in both transcription and anterior/posterior axis formation. 